\title{
When PATrons ARE NOt PATRONS: A SOCIAL-SCIENTIFIC READING OF THE RICH MAN AND LAZARUS (LK 16:19-26)
}

Author:

Ernest Van Eck ${ }^{1}$

\section{Affiliation:}

${ }^{1}$ Department of New

Testament Studies,

University of Pretoria,

South Africa

\section{Correspondence to: \\ Ernest Van Eck}

e-mail:

ernest.vaneck@up.ac.za

Postal address:

Department of New

Testament Studies, Faculty

of Theology, University

of Pretoria, Lynnwood

Road, Hatfield 0083, South

Africa

\section{Keywords:}

patrons; Lazarus; Luke's

Gospel; parables; clientism

\section{Dates:}

Received: 03 Feb. 2009

Accepted: 30 Jun. 2009

Published: 29 Sept. 2009

How to cite this article: Van Eck, E., 2009, 'When patrons are not patrons: A social-scientific reading of the rich man and Lazarus (Lk 16:19-26)' HTS Teologiese Studies/ Theological Studies 65(1) Art. \#309, 11 pages. DOI: 10.4102/hts.v65i1.309

\section{This article is available} at: http://www.hts.org.za

(c) 2009. The Authors. Licensee: OpenJournals Publishing. This work is licensed under the Creative Commons Attribution License.

\section{ABSTRACT}

This article presents a social-scientific interpretation of the parable of the rich man and Lazarus. Attention is first given to the history of the interpretation of the parable and to the integrity and authenticity of this interpretation. A social-scientific reading of the parable is then presented in terms of the strategy and the situation of the parable. In terms of the latter, the parable is read against the backdrop of an advanced agrarian (aristocratic) society in which patronage and clientism played an important role. Regarding the parable's strategy, it is argued that the different oppositions in the parable serve to highlight their only similarity: those who have the ability to help do not help. The gist of the parable is that patrons who do not act like patrons create a society wherein a chasm so great between rich and poor is brought into existence that it cannot be crossed.

\section{INTRODUCTION}

Social-scientific criticism, as an exegetical method, analyses texts in terms of their strategy (the pragmatic and rhetorical dimensions of the text) and situation (the social circumstances in which the text was produced). An analysis of the strategy of the parable of the rich man and Lazarus indicates that the many oppositions in the parable function to highlight their only similarity: the rich man and Abraham's unwillingness to attend to those in need. How is this possible, especially in the case of Abraham, the ultimate example of hospitality in the Jewish tradition? This question is addressed by looking at the important role that patronage and clientism played in the world of Jesus (which was an advanced agrarian [aristocratic] society), focusing inter alia on hospitium (the relationship between host and guest).

It is argued that the parable of the rich man and Lazarus is an illustration of the great class disparity that existed in first-century Palestine between the urban élite and the exploited rural peasantry. In the parable, the rich man symbolises the élite and Lazarus the exploited poor. The poor man's name - Lazarus - is not accidental: it typifies the way in which Jesus sided with the poor, with the expendables and the socially impure of his day. The gist of the parable is this: When patrons who have in abundance do not pass through the gate to the poor, a society is created wherein a chasm so great is formed between rich (the élite) and poor (the peasantry) that it can no longer be crossed. When this happens - when patrons do not fulfil their role as patrons - no one can become part of the kingdom neither Lazarus, nor the rich man. As such, the parable identifies Jesus' historical activity essentially as political (the restructuring of society) and not as religious or theological.

Attention is also given to the interpretation history of the parable and to the questions of authenticity and integrity. It is argued that the parable most probably ends in Luke 16:26 and embodies the nucleus of Jesus' teaching on topics like patronage, generalised reciprocity and the economic exploitation of the peasantry by the ruling élite. The parable can thus be traced to the historical Jesus.

\section{HISTORY OF INTERPRETATION}

The earliest interpretations of the parable of the rich man and Lazarus were the allegorical interpretations of Augustine, Gregory the Great and Ambrose (Wailes 1987:255-260). ${ }^{1}$ In an attempt to break away from these allegorical interpretations, Luther and Calvin employed a historical and literal approach to the parable (that can be typified as theological). They did not, however, succeed in avoiding the perils of allegorisation. ${ }^{2}$ Lazarus' sores to confession. In Augustine's view, Lazarus typifies the Christ figure, while Ambrose saw Lazarus as Paul. Gregory the Lazant (cir 540-604) in Great (circa 540-604) interpred the parable in the same vein. The rich man represents the Jews, who used the law for vain motives, while Lazal fall from the rich man's (the Jew's) table represent Jewish law and the licking of Lazarus' sores signifles healing, that is the confession of sins to the he eternal torment upon their lips as a result of the law that was on their lips but which they chose not to fulfil. Morally speaking, the parable cautions against ostentation, exalts the virtue of poverty and admonishes the believer to lose no opportunity for doing good works of mercy (Kissinger 1979:38)

2.Luther's historical-Christological interpretation of the parables entailed an interpretation of the Scriptures in their 'plain sense' (a plain and literal reading of the text without considering, if possible, hidden or symbolic meanings in the text). Each text has as reference point (centre of meaning) Jesus Christ (Luther's so-called 'Christum treibet' principle; see Kissinger 1979:44-45). Luther identified at leas three meanings in the parable of the rich man and Lazarus. Firstly, the parable teaches that it is not sufficient merely to do no evil and to do no harm but rather that one must be helpful and good. Secondly, the parable shows that God does not desire the dead to teach us, but that we should cling to the Scriptures. And, thirdly, it is an abominable and pagan practice, before the eyes of God, to consult the spirits and practise necrom (Kissinger 1979:45-46) In this the spirts and praction clearly vible, ing neglect the poor while they revel in pleasures and indulge themselves. Calvin also commented on the meaning of 'Abraham's bosom': it is a metaphor that points to the fact that God's children are strangers and pilgrims in the world, but if they follow the faith of their father Abraham, they will inherit the blessed rest when they die (cf. Torrance \& Torrance 1972:116-122). As was the case with Luther, Calvin's theological interpretation of the parable showed traces of the sola fidei principle of the Reformation, an allegorical reading of the parable in theological dress. See also Rauschenbush (1950:73-75), who replaced the sola fidei principle of Luther and Calvin with the concept of economic injustice: Jesus regards a life of sumptuous living and indifference to the want and misery of a fellow human at the doorstep as deeply sinful and immoral. This becomes clear in the parable, as the rich man is not accused of any crimes or vices but he is still sent to hell. 
The first historical-critical reading of the parable was that of Jülicher (1910[1886]:634), which identified two (loosely connected) parts in the parable: Luke 16:19-26 (the opposing and very different lives of the rich man and the poor Lazarus in this world) and Luke 16:27-31 (the complete and permanent reversal of the fortunes of the rich man and Lazarus in the afterlife) Jülicher's interpretation of the parable has, in a certain sense, dominated the interpretation of the parable until the presen in three ways. ${ }^{3}$ Firstly, most scholars divide the parable into two parts, ${ }^{4}$ 'an opinion that has been a staple of the scholarly literature ever since' (Hock 1987:449). Secondly, most scholars look for the main point of the parable in the second part ${ }^{5}$; some scholars, however, find the main point of the parable in the first part, ${ }^{6}$ while some identify a distinctive message in both parts ${ }^{7}$. Thirdly, scholars have proposed an array of extra-biblical stories that the first part of the parable supposedly borrowed from ${ }^{8}$ in this regard, however, there is also a difference of opinion.

So wealth is characterised as a dividing power, since it creates semi-human relations between social classes. Jesus thus tells the parable to warn the rich that they must show generosity before it is too late and they are also cast into hell as Dives (the rich man) was.

3.According to Herzog (1994:115), most interpretations of the parable are deeply indebted to the insight by Bultmann (1963) that the parable can be divided into two parts. Hock (1987:449), however, was correct when he stated that this division of the parable already formed part of Jülicher's analysis in 1910

4.See Hock (1987:449; note 5) for a list of scholars who interpret the parable by dividing it into the two parts identified by Jülicher (1910). To Hock's list can be added the interpretations of Gressmann (1918), Cadoux (1930), Smith (1937) and Oesterley (1936).

5.See, for example, Manson (1949), Jeremias (1972) and Fitzmyer (1985). The poin of view of Jeremias in this regard suffices. According to Jeremias (1972:182-186) of view of Jeremias in this regard suffices. According to Jeremias (1972:182-186),
the thrust of the parable (which should be named the parable of the six brothers; the thrust of the parable (which should be named the parable of the six brothers; Jones 1999:163) is that of 'the challenge of the hour', in which evasion is impossible. The emphasis of the parable is to be found in its added 'epilogue': the rich man's five
brothers - like their rich brother - live a careless life in selfish luxury, deaf to God's word and in the belief that death ends all. Jesus tells the parable to warn men (who resemble the brothers of the rich man) of the impeding danger. As such, the parable is not commentary on a social problem or a teaching on the afterlife but a warning to those for whom everything is at stake to make the right decision.

6.See, for example, Crossan (1973:66-68) and Scott (1989:146-151).

7.Bultmann (1963:210) divided the parable into two distinct parts, with a distinctive message expressed in each part. Luke $16 \cdot 19-26$ is a story based on a folkloric account of the reversal of fortunes in the afterlife and Luke 16:27-31 constitutes a polemic against the need for signs to augment the Torah and prophets for revealing the will of God. In following Bultmann, Smith (1937:135-141) argued that Jesus shifts the meaning of the traditional materials about the afterlife (Luke 16:19-26) to focus on the adequacy of the Torah (Luke 19:27-31); Oesterley (1936:208-210) was of the opinion that Luke 16:19-25 is addressed to the Pharisees, while Luke 16:27-31 was spoken to correct Sadducean beliefs; and Cadoux (1930:124-128) saw Luke 16:19-26 as an authentic parable of Jesus that was used in his debate with the Pharisees over the importance of signs (Luke 16:27-31).

8.This idea was first championed by Gressmann (1918), who identified the Egyptian folk-tale of the journey of Si-Osiris, the son of Setme Chamoïs, to the underworld as a parallel for Luke 16:19-26. Jeremias (1972:182-183) and Bultmann (1963; see also Smith 1937:54), however, saw a Jewish legend (a folk-tale about a rich and godless married couple) as a parallel for Luke 16:19-26. According to Jeremias (in following the work of Salm; Jeremias 1972:178), Jesus used a Jewish version of the story of Gressmann's Egyptian story of Setme. Alexandrian Jews brought this story to Palestine, where it became popular as the story of the rich tax collector Bar Ma'jan and a poor scholar, a story that found its way into the (Aramaic) Palestinian Talmud (j. Sanh. 6.23c par; j. Hagh. 2.77). This folk-tale ends where Bar Ma'jan stands at the bank of a stream, unable to reach the water (= Lk 16:26). Bultmann (1963:203) saw Luke 16:19-26 as a Jewish legend, a variation of the above-mentioned Egyptian and Jewish folkloric story based on a folkloric account of the reversal of fortunes in the efterlfe. According to Hock (1987:447-463), the first part of the parabo points the afterlfe.According to a Greco-Roman paret we find two stories rich man and Lazarus with comparisons and characterisation through dialogue (Hock 1987:457). The two stories tell how and why Megapenthes (the rich man in Cataplus) is sent to Hell: his use of his wealth, licentiousness, sexual offences, murders, confiscations, arrogance and money lending (hedonism). In the end, it is a question of self-control (Micyllus) and no self-control (Megapenthes) that seals their fate. According to Hock, all this is paralleled in the parable: the rich man is compared with Lazarus in terms of his hedonism. The parable thus has a Cynic colouring: Lazarus is the good one because his life of poverty excludes him from the damning life of the rich man. In short, in this parable, Jesus the Cynic is speaking (Hock 1987:457-462). Finally, Aalen (1967:1-13) and Nickelsburg (1979:324-344) noted parallels in 1 Enoch (also see Snodgrass 2008:420-423 for other possible parallels). Almost all scholars who identified an extra-biblical parallel for the first part of the parable were of the opinion that Jesus uses an extrabiblical tale and reinterprets it parable were of by adding a cor parable (Jeremias 1972:183).

9.According to Pax (1975:254-268), the Oriental social experience itself is sufficien to explain the similarities between the parable and the folk-tale. Hultgren (2000:111)
Hock has aptly described this direction that the interpretation of the parable took:

For decades, we have seen, scholars have been investigating the parable within the framework that goes back to the first part of (the previous - EvE) century. Since Jülicher, scholars have virtually accepted as a given the division of the parable into two parts. Since Gressmann scholars have looked to an Egyptian folk-tale for the background of at least the first part of the parable and for the interpretation of details in the parable. And since Bultmann, scholars have increasingly had to decide whether Jesus or the church is the origin of the parts of the parable.

(Hock 1987:451)

Jülicher's interpretation of the parable, however, has influenced almost all subsequent interpretations of the parable in yet another way. According to Jülicher (1910:317), the main point in the parable of the rich man and Lazarus is that the parable shows the ultimate consequences of a life of wealth and pleasure. Almost all subsequent interpretations of the parable have come to more or less the same conclusion: the parable's moral point is about the dangers that arise from the love of wealth, a command to take care of the poor, a warning to the rich to heed this command and a condemnation of the rich who ignore this warning. In the words of Snodgrass:

From the earliest days interpreters have focused on the parable's moral impact with its denunciation of the wealthy who neglect the poor. Other options are minority opinions. In modern critical studies most interpreters still see the parable as denouncing the misuse of resources and the neglect of the poor.

(Snodgrass 2008:426)

When one looks at most modern critical studies of the parable, this indeed seems to be the case. Moreover, it also seems that, whatever the approach, the result of the interpretation is more or less the same. Differences are those of emphasis. The following examples substantiate this point.

Most scholars who regard the parable as a Lukan composition or interpret it in terms of its narrative context in Luke have found some moral lesson about the rich (the dangers that arise from the love of wealth) and the poor (or poverty) in the parable, a well-established motif in Luke (and Acts). ${ }^{10}$ According to Bultmann (1963:203), the parable (Lk 16:19-26) intends to tell the poor to be contented with their lot, while Talbert (1982:156-159) saw the parable as a command to take care of the poor (Dt 15:7-11) and as a condemnation of the rich. Hultgren (2000:115) reads the parable in the same vein: the parable serves to warn the rich about the perils of neglecting the needs of the poor, even (and especially) of those to whom it would be socially acceptable to be indifferent ${ }^{11}$ ( $c f$. Donahue 1988:171; Perkins 1981:2). This is also the opinion of Schottroff (2006): the parable forms part of Luke 16, which is 'a chapter of halakah on the subject of money, from the perspective of the Lukan communities' (Schottroff 2006:160), and, in this context, communicates that a good life based on the misery of the poor is not part of the kingdom. In the kingdom, money should be used

held the same view: although stories about the fate of the rich and the poor in the afterlife are abundant, the parable is not an exact replica of any of these. While it is related to common folklore it is a creation in its own right. Recently, Snodgrass is related to 428 ) a (2008.426-428) also argued that any specific extra-biblical parallel for the parable is unlikely. There are dozens of stories in various cultures over thousands of years that , Epic, the Egyptian and Jewish accounts. The Gospel story uses common folkloric motifs shared by several cultures: descent to the underworld, reversal of circumstances, and denunciation of the rich for their neglect of the poor' (Snodgrass 2008:427). Lucian's use of these themes in a variety of works also shows that even an indirect dependence on a specific account is not likely.

10. Hughes (1993:29-41) is one exception in this regard. According to him, Luke gives, in this parable, the reason why the early followers of Jesus failed so miserably in their attempt at the evangelisation of the Jews.

11.Hultgren (2000:115) sees the parable, in its present Lukan form, as a Christian allegorisation that goes back to a nucleus that can be attributed to Jesus. This 'nucleus' had the same meaning as its present Lukan form, that is 'the teachings of God concerning care for the poor are clear in the law and the prophets' (Hultgren 2000:115). 
rather for the universal liberation of people to be made a reality. Snodgrass, who defines the parables as expanded analogies used to convince and persuade (stories with intent; Snodgrass 2008:9) and interprets the parables in terms of their narrative contexts in the canonical gospels (Snodgrass 2008:20), ${ }^{12}$ comes to the same conclusion. The parable has two equally important themes: judgement on the use of wealth and the sufficiency of the Scriptures. The parable expresses God's identification with the poor. The error of the rich man (who is a child of Abraham) is the neglect of the poor and those in need, including Lazarus (who is also a child of Abraham). The children of Abraham are those who obey Moses and the prophets and who share their wealth with the poor. This is also the result of the analysis of the parable by Leonhardt-Balzer (2007:647-660): the main focus of the parable is the rich man and the name 'Lazarus' is a symbol for all poor people. The Torah and the prophets emphasise the social responsibility of the rich to care for the poor (LeonhardtBalzer 2007:657) and the hearer of the parable is called either to identify or not to identify with the rich man (Leonhardt-Balzer 2007:651).

Scholars likeSmith ${ }^{13}(1937)$, Stein $^{14}(1981)$, Herzog (1994) and Hock (1987) who, like Jülicher (1910) (and Jeremias [1972]), attributed both parts of the parable to Jesus (with either Lk 16:19-26 or Lk 16:19-31 stemming from Jesus) formulated the main point of the parable in a similar vein as did Jülicher ( $c f$. Schweizer 1984:262). According to Smith, in the parable, Jesus equates poverty with piety and wealth with ungodliness and he states that the measure of a person's fitness to enter the kingdom is his readiness to do without the things of this world. Stein defines the parable as a story parable (a parable that refers to a singular event) and as an example of those teachings of Jesus that involve the generous use of possessions. More specifically, the parable says that love is manifested by the wise use of one's possessions to perform acts of love. Although the rich man did not actively harm Lazarus, his sin was that he did Lazarus no positive good (Stein 1981:79, 111, 135). Herzog (1994:128-129) sees the central contrast of the parable as the great class disparity between the urban élites (the rich man) and the desperate expendables (Lazarus). As such, the parable codifies the relationship between rich and poor in first-century Palestine and is representative of Jesus' pastoral attitude towards the poor. The parable is good news for people like Lazarus but bad news for the rich: in the afterlife, the situation of this life will be reversed; Lazarus will take part in the eschatological banquet simply because he was poor (see also Segundo 1985:114). Hock (1987:447-463), who suggests that Graeco-Roman intellectual traditions (especially Cynic views on wealth and property) should be seen as the cultural bedrock of the parable, understands the parable as a harsh charge against the rich (especially against hedonism), while Lazarus is judged innocent because of his poverty (Hock 1987:462). ${ }^{15}$

12.Snodgrass (2008:20) saw the context given by the Evangelists as the proper framework for interpreting the parables, since the parables express 'the general context of the ministry of Jesus in first century Palestine' (Snodgrass 2008:20). $\mathrm{He}$ also states the following: 'Jesus' parables may not legitimately be torn from that context and placed elsewhere. To do so will not allow interpretation of Jesus' parables, nor allow hearing him, but will make one a creator of a new parable with parables, nor allow hearing him, but will make one a creator of a new parable with absconded materials' (Snodgrass 2008:20). The implication of Snodgrass' point of view is that there is no difference between the parables as spoken by the historical esus and the versions thereof in the gospels, even are not the context of Jesus' first-century (Galilean) Palestine.

13.The process of parabolic transmission, Smith (1937) argues, makes it possible that the majority of the parables in the synoptic Gospels represent authentic parables of Jesus. Also, since Jesus' teaching on poverty and wealth was a fundamental part of his eschatological gospel, the parable of the rich man and Lazarus most probably goes back to Jesus himself.

14.Stein (1981:38-39) bases his contention that most of the Synoptic parables go back to Jesus on two arguments. Firstly, the parables meet the criterion of dissimilarity or distinctiveness (the parables of Jesus do not derive from the Judaism of Jesus day or from the early church). Secondly, the content and language of the parables agree with what is found in other sayings of Jesus'

15. The opinions of Cave (1969), Wright (1996), Cadoux (1930:80-115), Hunter (1960), Oesterley (1936.208-210) and (1996), Cadoux (1930:80-115), Hunter as exceptions. According to Cave (1969:319-325) and Wright (1996:255-256), the parable describes how Jesus, during his ministry, welcomes the sinners (Lazarus
Scholars who attribute only the first part of the parable to Jesus also relate the meaning of the parable to the dangers that arise from the love of wealth and the responsibility of the rich towards the poor. ${ }^{16}$ The interpretation of the parable by Scott (1989:141159) can serve as an example here. In his interpretation of the parables, Scott focuses on the social dynamics of first-century peasant culture (Scott 1989:4) and on the linguistic, mythical and wisdom traditions in which the parable of Jesus operates (Scott 1989:68). According to Scott (1989:155-159), the parable is one of boundaries and oppositional parallels. The most important oppositional parallel in the parable is that of space: the rich man is inside and Lazarus is outside. As such, these oppositions reflect the limited-goods society of the first-century Mediterranean world, where the social status of the poor and the rich is fixed. The hinge that binds the oppositional parallel of space is the gate: it can let in or keep out. The rich man's fault is that he does not pass through the gate to help Lazarus. The kingdom does provide a gate to the neighbour; this gate means grace and is a metaphor for the kingdom. The parable attacks the blindness that does not see the gate's purpose and

subverts the complacency that categorizes reality into rich and poor or any other division. The standard is not moral behavior as individual, isolated act, but the ability to pass through the gate, metaphorically, to the other side; solidarity.

(Scott 1989:159)

In short, the parable states that the kingdom of God is the manifestation of God's righteousness in the face of injustice' (Scott 1989:157).

Finally, Via's interpretation of the parable can be mentioned: Via (1972:114-119), who approaches the parables as aesthetic objects and employs a structuralist reading, ${ }^{17}$ defines the parable as an example story, an illustrative example of what one is to do or not to do. From this point of view, the parable states simply that one should look after the poor.

\section{INTEGRITY AND AUTHENTICITY}

Although there is scholarly 'consensus' (more or less) on the main point of the parable, \$2 clearly indicates that scholarly opinion is divided on the integrity and authenticity of the parable. Some scholars argue that the parable cannot be attributed to Jesus. These scholars either defend the integrity of the parable (with the first part paralleled in extra-biblical literature and the second part added by Luke or the early church, forming a unit [Hughes 1993], or with the whole parable being a Lukan composition [Hultgren 2000; Perkins 1981; Schottroff 2006]) or opt for the parable consisting of two parts (with the first part paralleled in extra-biblical literature and the second part added by Luke or the early church, not forming a unit [Beare 1962; Bultmann 1963; Donahue 1988; Funk, Hoover

as symbol of the poor in Abraham's bosom), a sign that the return from exile or resurrection has started. As such, the parable is a warning directed at the Pharisees or at Israel in general) to repent. Cadoux (1930:80-115) argues that the parables of Jesus must be understood within the context of Jesus' relationship with the Jews. Jesus uses parables only in situations where controversy reigns. As such, Jesus' parables have a polemical and apologetic intent. Jesus tells the parable as a response to the Pharisees' request for a sign from heaven (Mk 8:11-12): a sign from heaven is not necessary, since heaven knows that a sign from hea is un from heaven is not necessary, since heaven knows that a sign from heaven 作 (2002:346) sees the main point of the parable as the importance of living by the Word of God (i.e. Moses and finally, sees the first part of the parable as addressed to the Pharisees and the second part as addressed to the Sadducees to correct their belief about the afterlife.

16.One exception in this regard is the interpretation of Crossan. Crossan (1973:33-35) dentified three basic categories of parables that Jesus tells: parables of advent, reversal and action. The parable of the rich man and Lazarus (Lk 16:19-26) falls under the category of reversal. In the parable, the rich man becomes 'poor' and the poor Lazarus becomes 'rich'. As such, the kingdom shatters and reverses everything that seems certain and firm. Jesus is not interested in moral instruction about riches - the parable is about the reversal that comes with the kingdom's advent.

17. In his structuralist reading of the parables, Via (1972) distinguishes between the story and the discourse of a parable (the identified story in the text that is to be interpreted), then analyses the parable from an actantial point of view (which interpreted), then analyses the parable from an actantial point of view (which
enables the reader to understand the identified story) and, finally, translates the enables the reader to understand the identified story) and, finally, translates the
vehicle of the parable (that which is well-known) into the tenor, which makes the parable a parable of the kingdom of God. 
\& The Jesus Seminar 1993; Mealand 1980; Montefiore 1909), or with the option that both parts stem from the early church [Horn 1983]).

Scholars who do argue for the authenticity of the parable also either defend the integrity of the parable (with both parts stemming from Jesus to form a unit [Herzog 1994; Hock 1987; Leonhardt-Balzer 2007; Schnider \& Stenger 1979; Snodgrass 2008; Stein 1981; Talbert 1982]) or argue that the parable consists of two separate narratives (with the first part paralleled in extrabiblical literature used by Jesus and the second part stemming from Jesus [Fitzmyer 1985; Gressmann 1918; Hendrickx 1986; Jeremias 1972; Jülicher 1910; Manson 1949; Marshall 1963; Smith 1937; see also the list by Hock 1987:449-450, fn 7l or with only the first part stemming from Jesus and the second part added by Luke [Crossan 1973; Oesterley 1936; Schottroff \& Stegemann 1978; Scott 1989] or with parts being authentic sayings of Jesus [Cadoux 1930]).

It is the contention of this essay that a choice, with regard to the above possibilities on the integrity and authenticity of the parable, has to be made before an own interpretation (using a social-scientific approach) can be made. In the two sections that follow, arguments are put forward first for the parable ending in Luke 16:26 (\$3.1) and then for the possible authenticity of Luke 16:19-26 (\$3.2).

\section{Where does the parable end?}

Scholars who defend the integrity of the parable are, inter alia, Hughes (1993; see again note 10), Perkins (1981), Hultgren (2000), Schottroff (2006), Stein (1981), Talbert (1982), ${ }^{18}$ Hock (1987), ${ }^{19}$ Herzog (1994), ${ }^{20}$ Leonhardt-Balzer (2007) and Snodgrass (2008) ${ }^{21}$. If Luke 16:19-31 is seen as a Lukan composition (Hultgren 2000; Perkins 1981; Schottroff 2006) and as part of Luke 16, a wellknit literary composition in itself (see especially Schottroff), the parable's integrity is above suspicion. From this point of view, Luke 16:19-31 and Luke 16 would obviously be a cohesive unit. This, of course, is also true of the whole of Luke-Acts; Luke is known for the careful way in which he structured his narrative as a double act. What if, however, the parable is taken from its Lukan context and a possible historical Jesus setting for the

18. Talbert (1982) argues that the parable is part of a carefully constructed unit (Lk 16) and functions as Luke's answer to Luke 16:14-18. The first part of the parable (Lk 16:19-26) refers to Luke 16:14-15 and demonstrates the ambiguity of wealth as a sign of God's blessing. As such, it fulfils Luke 16:15b. The second part of the parable (Lk 16:27-31) exemplifies Luke 16:16-18. The law is still in force (as the parable (Lk 16:27-31) exemplifies Luke 16:16-18. The law is still in force (as the witness of Moses and the prophets indicate; Lk 16:29) and therefore
command to take care of the poor (Dt 15:7-11; Talbert 1982:156-159).

19. Hock (1987) bases the unity of the parable on the following arguments. Firstly, the Egyptian folk-tale is not a close literary parallel for the parable and thus not essential for understanding the parable. Secondly, the opening verses of the parable (Lk 16:19-21) depict the contrast between the rich man and Lazarus, which prepares the principal action of the parable (their deaths in verse 22 and their reversal of fortunes in verse 23) with the following dialogue between Abraham and the rich man ( $L k$ 16:24-31), underscoring the permanence of this reversal and of the rich man. If one breaks the parable in Luke the negative che (Lecte in Luke 16:26, it divides the dialogue between Abraham and the rich man in the middle (Hock 1987:454, 462). For a critiqu
Funk et al. and Crossan below.

20.According to Herzog (1994:129), 'the unity of the parable lays in the way the description of social classes in the first part sets up the exhortation to read Mose and the Prophets in the second part'. Herzog also argues that the parable is not a story about two abstract social types but a story about representatives of two social classes, the urban elite and the desperate expendables, and serves as a codifying legitimisation of these two social classes in first-century Palestine. If one looks at Herzog's interpretation of the parable closely, one can indeed ask if his interpretation really needs the second part of the parable.

21.When one compares the parable with other descent stories and the theme of the revelation of the fate of the dead to the living (Lk 16:27-31; like the story of Setme and its Jewish counterpart, Jannes and Jambres, and several Greek accounts), one would expect such a continuation of the story as we have it in Luke 16:19-31. If the narrative ended at Luke 16:26, the story would be left incomplete. Moreover, recent literary analyses do not divide the story merely into two sections separated at Luke 16:26, the middle of the dialogue between the rich man and Abraham. The parable should be divided into three parts, not two: Luke 16:19-21,22-23 and 24 31. As such, the parable 31. As such, the parable provides two snapshots (before and are and a dialogue. , a unity that is evidenced by the parallels between Luke 16:24 and Luke 16:27 (Snodgrass 2008:427-428). What if however, the parable is not read as a descent story? parable is proposed? Does the literary unity of Luke 16 not suggest that the parable was appended or reworked to fit into its literary context? Put differently: Does the literary unity of Luke 16 not in and of itself propose Luke 16:27-31 as an addition? If, however, one argues (like Leonhardt-Balzer) that the two parts of the parable, as opposite poles, need one another, one could also argue that all the opposites in the parable already occur in the first part and that the second part introduces a new theme (the validity of the prophets and the Torah) that is not necessary for the first part to function as a cohesive unit on its own. And if one sees the unity of the parable in the conviction that both parts stem from Jesus (Talbert), this automatically means that Jesus must have told these two parts as one parable. Have we any evidence to support this point of view? As we have seen, Jülicher's, Jeremias', Bultmann's, Oesterley's and Cadoux's points of view on the integrity of the parable contradict this possibility.

The strongest arguments against the integrity of the parable have come from Funk et al. (1993:362), Crossan (1973:67) and Scott (1989:144-146). Funk et al. (1993:362) argue that Luke 16:27-31 has, as content, the early Christian theme of the Judean lack of belief in the resurrection of Jesus (cf. Lk 16:31, a clear reference to Jesus). Moreover, the testimony of Moses and the prophets, appealed to in verses 29 and 31, resonates with the resurrection stories in Luke 24:13-35 and 24:36-49 (especially Lk 24:27 and 44). ${ }^{22}$ The ending of the parable is therefore most probably a Lukan creation (Funk et al. 1993:362).

Crossan (1973:67) and Scott (1989:144-146) also doubted the possibility of Luke 16:27-31 being part of the parable, viewing it as an added piece of tradition from the early church, reworked by Luke to fit his interests. According to Crossan, the conclusion of the parable fits the style and programme of Luke-Acts, and a clear parallel between Luke 16:27-31 and Luke's account of the resurrection in Luke 24:44-47 can be indicated. Crossan notes the following parallels: the theme of disbelief (Lk 16:29, 31 and Lk 24:12, 25, 41); the use of Moses and the prophets (Lk 16:29, 31 and Lk 24:27, 44); the use of o'viornu in Luke 16:31 and 24:46 (the verb 'to rise up' is used with 'from the death' only in these two occurrences in Luke); and the use of the theme of repentance (Luke $16: 30$ and Ac 2:38; 3:19; 8:22; 17:30; 26:20). ${ }^{23}$

In support of Crossan, Scott (1989:145) also noted the parallel

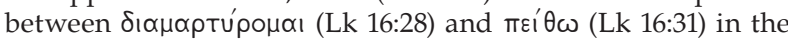
parable's conclusion ${ }^{24}$ words that are frequently used in Acts (see Ac 18:4-5; 28:23). All this, according to Crossan and Scott, indicates a Lukan hand in the conclusion of the parable in order for the parable to fit his apologetic needs. The conclusion was therefore most probably not part of the original parable and either was appended to relate the parable to Jewish disbelief in Jesus' messiahship (Scott 1989:146) or has, as content, the early Christian theme of the Judean lack of belief in the resurrection of Jesus (Funk et al. 1993:362).

The arguments of Funk, Crossan and Scott seem compelling enough to conclude that the parable most probably ended in

22. The implication of the argument of Funk et al. is clear: if the parable goes back to Jesus, the second part cannot come from Jesus (otherwise one has to assume that Jesus is 'foretelling' his resurrection). One must also bear in mind that both the resurrection stories that Funk et al. refer to are Lukan-Sondergut, which makes the appeal to Moses and the prophets in Luke 16:29 and 31, and Luke 24:27 and the appeal to Moses and the prophets in Luke $16: 29$ and 31 , and Luke $24: 27$ and 44 most probably a Lukan creation. Even in the light of this evidence, Snodgrass
(2008:428) calls the similarities between Luke 16:27-31 and the resurrection story in Luke 24 'superficial'.

23.For a detailed discussion of Crossan's arguments (1973), see Scott 1989:142-143. With regard to Crossan's last parallel, Luke's use of the theme of repentance in Luke 16:30 and the kerygmatic speeches in Acts, Scott (1989:143, note 8) notes that Crossan might have added Acts 5:31,11:18 and 20:21. Scott also opines that Crossan could have made his case even stronger if he had also noted the parallels between the theme of repentance in Luke 16:30 and the Gospel itself ( 11:32; 13:3, 5; 15:7, 10; 17:3-4; Scott 1989:144).

24.Diamartyromai occurs nine times in Luke-Acts, and only in this parable in the Synoptics. Peithō is used 21 times in Luke-Acts, 32 times in the New Testament Synoptics. Peithō is used
(Scott 1989:145, note 13). 
Luke 16:26: 'Once Abraham pronounces the chasm, the great dividing line, the story has reached its conclusion' (Scott 1989:146).

\section{The authenticity of Luke 16:19-26}

Most scholars who question the authenticity of Luke 16:19-21 base their arguments on the possibility of the parable being paralleled in folkloric stories/legends of the reversal of fortunes in the afterlife (Beare 1962; Bultmann 1963; Donahue 1988; Gressmann 1918; Hughes 1993; Jeremias 1972,,25 Mealand 1980; Montefiore 1909). Some argue for a parallel in the Enoch literature (Aalen 1967; Nickelsburg 1979), while others see the whole parable as being a Lukan composition (Hultgren 2000; Perkins 1981; Schottroff 2006; Talbert 1982) or as stemming from the early church tradition (Horn 1983).

The Jesus Seminar was divided about whether the story is traceable to Jesus and voted the parable grey (Funk, Scott \& Butts 1988:64; Funk et al. 1993:361). The Fellows of the Jesus Seminar, who questioned the authenticity of the parable, supported the argument that folk-tales about the reversal of fates in the afterlife were widespread in the ancient Near East. They also noted the following features of the parable that most probably make it a Lukan composition (Funk et al. 1988:64; Funk et al. 1993:361): the parable is the only parable that gives characters proper names (cf. Scott 1989:141); attention to the poor is a special characteristic of Luke, ${ }^{26}$ and the bosom of Abraham (Lk 16:22) is most probably an allusion to Luke 3:8. Scott (1989:141) also doubts the authenticity of the parable, since it is the only parable that depicts a scene from the afterlife.

Scholars who argue the opposite note that there were 'dozens of stories in various cultures over thousands of years that tell of trips to the realm of the dead, often castigating the rich' and that 'the use of preexisting materials is evident in other parables and would not be surprising' (Snodgrass 2008:426, 427). The parable does differ in many respects from its Egyptian and Jewish counterparts: the folk-tales in the ancient Near East normally include a judgement scene, which this parable does not (Funk et al. 1993:361), and, in the parable, the fates of the rich man and Lazarus are simply reversed, reminiscent of Jesus' technique of storytelling ${ }^{27}$ (Funk et al. 1988:64). Moreover, known folktales about rich and poor understand rich and poor mostly in economic terms. This is not the case in Luke. The relationship parallels between the parable and the available folk-tales are, in any case, only indirect and 'neither as compelling nor as explanatory as these claims suggest' (Bauckham 1998:97-118; Hock 1987:452). The fact that these tales do exist only highlight the point that Luke wants to make (Funk et al. 1993:361). And if a popular tale does, in fact, lie behind the parable, this does not automatically mean that the parable could not have been told by Jesus (Hock 1987:452; Hultgren 2000:111; Snodgrass 2008:427).'While it is related to common folklore, it is a creation in its own right' (Hultgren 2000:111).

With regard to the proper names in the parable, scholars argue that the name 'Lazarus' is not accidental but essential to the meaning of the parable (Funk et al. 1988; Funk et al. 1993; Herzog 1994; Hultgren 2000; Scott 1989; Talbert 1982). The same holds true for Abraham. The introduction of Abraham in Luke 16:22 is not because of Luke 3:8 but because of the theme of hospitality in the parable. In this regard, Abraham is a suitable figure for heavenly reward, as he was rich but also well known for his

25.Luke's use of the historic present $\lambda \epsilon \gamma \epsilon \mathrm{L}$ also indicates that the parable consists of pre-Lukan material (Jeremias in Scott 1989:146, note 18). Of the 90 examples of the historic present in Mark, Luke retains only one (Lk 8:49). There are, however, five historic presents in the Lukan parables (Lk 13:8; 16:7; 16:23; 16:29; 19:22), clear evidence for an underlying pre-Lukan tradition in theses parables.

26. Luke, for example, contrasts the blessedness of the poor with the condemnation of the rich in his first beatitude and woe (Lk 6:20, 24; Funk et al. 1988:64).

27.For example, Matthew 20:1-15, Q 14:16-24 ([Mt 22:2-13/Lk 14:16-4]/GThom 64:1-11) and Luke 15:11-31 (Funk et al. 1988:64) hospitality (Funk et al. 1988:64). The rich man is not pictured negatively for being rich but rather for his indifference and lack of hospitality (Funk et al. 1988:64). The contrast between rich and poor in the parable is therefore most probably not a creation of Luke's - Luke would have condemned the rich man simply because he was rich. The parable also parallels Luke 11:5-13, another parable of Jesus' that has hospitality as theme, together with the crossing of accepted cultural boundaries (an obvious theme in Luke 16:19-26). It also parallels Matthew 18:23-55, which also depicts the indifference of a rich man (one that has) to a poor man (one that does not have) in a wrenchingly pathetic situation (Funk et al. 1993:361). Finally, the reversal of fortunes in the parable echoes Q 6:20/GThom 54, a saying that most probably goes back to Jesus.

Can the parable be traced back to the historical Jesus or is it a preLukan or Lukan composition? The arguments for and against its authenticity do not seem to outweigh one another. Can one also argue that the parable goes back at least to a nucleus of Jesus' teaching on topics like patronage, power and privilege, class, status and the economic exploitation of the peasantry by the élite? Moreover, can a social-scientific interpretation of the parable help in answering these questions? This possibility will now be explored.

\section{A SOCIAL-SCIENTIFIC INTERPRETATION OF LUKE 16:19-26}

\section{Social-scientific criticism: A short definition}

'Social-scientific criticism ... studies the text as both a reflection of and a response to the social and cultural settings in which the text was produced' to determine 'the meaning(s) explicit and implicit in the text, meanings made possible and shaped by the social and cultural systems inhabited by both authors and intended audiences ${ }^{28}$ (Elliott 1993:8). Social-scientific criticism approaches texts as units of meaningful discourse that express (because of their ideological dimension) certain ideas and beliefs (cultural perceptions, values and world views), that describe social relations, behaviour and institutions and that serve to motivate and direct social behaviour. As such, texts either legitimate social institutions or serve as vehicles of social change (Elliott 1993:49-51). Social-scientific criticism, as exegetical method, analyses texts in terms of their strategy and situation. The situation of a text refers to the social circumstances in which the text was produced (Elliott 1993:54-55) and the text's strategy refers to

its pragmatic and rhetorical dimension (its structure - EvE), the manner in which the text in its totality of form and content (syntactic and semantic dimensions) is designed to have a specific effect upon... [its] ... receiver(s).

(Elliott 1993:55)

\section{Interpretations of the parable employing aspects of a social-scientific reading}

The interpretation history of the parable of the rich man and Lazarus indicates that not much has been done in terms of a social-scientific analysis of the parable, except for the interpretations of Scott (1989:141-151), Hultgren (2000:110-118) and Herzog (1994:114-131). These readings of the parable,

28.Elliott (1993:36-59) lists the following salient features of the social-scientific approach: it considers all knowledge as socially conditioned and perspectival in nature; it distinguishes and clarifies the differences between the social location of the interpreter and the social location of the authors and objects to be interpreted; it tries to avoid a text (by distinguishing between emic and etic inf the text); it employs theories and models as critical tools to clarify the differences between the contexts of ancient texts and of modern readers; it involves a process of logic that can be characterised as abduction; it considers the social and cultural models constructed on the basis of research and data pertaining to the geographical, social and cultural region inhabited by the biblical communities, that is the area of the circum-Mediterranean and ancient Near East; it presumes that this method is different from but complementary to a historical orientation; it holds the presupposition that the study of 'religion' in the Bible and its environment requires a study of social structures and relations; it draws on the full range of requires a study of socit suct the original meani the original meaning also with the aggregations of meanings down through the centuries. 
however, do not explore the full potential of a social-scientific interpretation of the parable. ${ }^{29}$ To this we now turn.

\section{Luke 16:19-26: A social-scientific reading The strategy of the parable: Not only oppositions but one important similarity \\ Emics}

Almost all interpretations of the strategy (structure) of the parable focus on the oppositions in the parable and describe them in detail ${ }^{30}$ The first three verses of the parable introduce the first two characters of the parable: one inside the gate ${ }^{31}$ (the one to whom the gate belongs) and one outside the gate. The man inside the gate has no name ${ }^{32}$, is described as rich, puts on purple and fine $\operatorname{linen}^{33}$ and feasts sumptuously every day

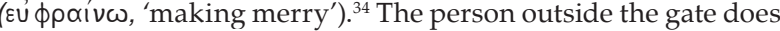

29. In his analysis of the parable, Scott (1989:146) typifies the parable as a story of boundaries and opposite parallels and understands the different locations of the rich man (inside the gate) and Lazarus (outside the gate) as reflecting the limited-goods society of the first-century Mediterranean world where the socia status of the poor and the rich are fixed (Scott 1989:151). He also opines that the relationship between the rich man and Lazarus implies a relationship of patron and client (Scott 1989:150). In his analysis of the parable, he does not, howeve explore this possibility any further, except for putting forward the question, 'Will the rich man use the gate to come to Lazarus' aid?' (Scott 1989:150). Hultgren states that 'the parable presupposes an ancient agrarian economy in which a person like Lazarus is more than just poor' (Hultgren 2000:115-116). The implications of this statement, namely that being poor in first-century Palestine was not simply a case of being economically poor but that it also refers to people who could not maintain their inherited statuses due to debt, to the exploitative practices of the elite (like the rich man) and to sickness (Malin 1981:85), are not further explored by Hultgren. rich man) and to sickness (Malina 1981:85), are not further explored by Hultgren. Herzog (1994:117-130) opines that the parable assumes the social structure of an advanced agrarian society and that, in the rich man and Lazarus, it brings togethe the two extremes of that social structure (class disparity and the difference between city and countryside and the oppressive system that it incorporates). Lazarus is depicted as either the second or third son of a peasant farmer who has lost his land because of the wealth accumulated by the systemic exploitation of the poor (throug taxes, the oppressive foreclosure of mortgages by the urban élite and the twisting of the Torah), who then becomes a day labourer and, finally, who drifts to the city to become a beggar. During his descent from former landowner or excess child of a peasant household to day labourer and, finally, to beggar, Lazarus most probably seeks patronage but fails. He probably does not find work, becomes malnourished and can no longer compete for work. He becomes vulnerable to disease, which later makes even begging impossible. This reading of the parable shows much potential, especially if one takes into consideration that Herzog sees the parable as stemming from the historical Jesus. Herzog, however reads the parable as as stemming trom the historical Jesus. Herzog, however, reads the parable as pedago parable to address the principle of patronage and the wealth accumulated by the systemic exploitation of

0.See especially the very good analysis by Scott (1989:146-155). Because of the limitation of space, not all the oppositions and parallels in the parable are noted and/or discussed here. The focus of this essay is not the oppositions in the parable either but the one important similarity (see below).

31.According to Marshall (1978:635), this gate was most probably 'a large ornamental gateway to a city or a mansion'. Oesterley (1936:205) opines that the gate indicates 'a nobly built mansion'. If this is the case, then even the gate to the rich man's house exemplifies his wealth.

32. In an attempt to remedy this seeming anomaly in the parable, various names have been attached to the rich man. $\mathrm{p}^{75}$ (third century, Alexandrian) gave him the name been attached to the rich man. $p^{75}$ (third century, Alexandrian) gave him the name
of Neu/hv and the ancient writer Priscillian (died $385 \mathrm{CE}$ ) named him Finees. The of Neu/hv and the ancient writer Priscillian (died $385 \mathrm{CE}$ ) named him Finees. The
Vulgate (fourth century, Western) opened with the words 'homo quidam erat dives', that is, 'a certain man was rich'. This phrase popularly came to be understood a 'there was a certain man, Dives'. This is why the parable is sometimes named the parable of Dives and Lazarus (Hultgren 2000:111; Leonhardt-Balzer 2007:651)

33. The man's richness is exemplified by the clothing that he wore and by his eating habits (see note 34). Purple clothing and fine linen were rare and very expensive 1937:135; the diffult process of oblaing the best dye from 1937.135, Snodgrass 2008:425). 12000 purple snalls produed only one gram of purple dye (Leonhardt-Balzer 2007:651-652). luxurious living, the colour of kings (Jdg 8:26; Es 8.15; 2 Sm 1.24; Ezk 23:6; D 18.12; see also Midrash Rabbah: and worn by those who were proud of their wealth (e.g. 1 Macc 8.14; 1 Esdr 3:6; Mk 15:17; cf. Hultgren 2000:112). Purple was also a sign of official power and honou (Scott 1989:148). Generals often honoured brave soldiers with purple-bordered robes (Seneca, Benefits 1.5.3), for example. The purple that the rich man wor thus insinuates that he lived like a king, was wealthy and honourable and occupied a position of privilege and power (Fitzmyer 1985:1130). The fine linen that he wore was most probably from Egypt, the most luxurious fabric of the ancient world (Herzog 1994:117-121; Jeremias 1972:183; ; Manson 1949:295). This fine linen is referred to in 1 Chronicles 2:13 and Ezekiel 27:16 as luxury articles (LeonhardtBalzer 2007:651).

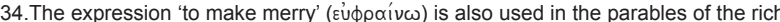
fool (Lk 12:19) and the prodigal son (Lk 15:23, 24 and 32) and means 'to make fool (Lk '12:19) and the prodigal son (Lk 15:23, 24 and 32) and means 'to m the otherwise boring and monotonous existence of Mediterranean peasants' (Scott 1989:14). See also Louw and Nida (1988:303, 25.131), who translated Eủ póive $1989: 14)$. See also Louw and Nida (1988:303, 25.131$)$
as 'to make glad, to cheer up, to cause to be happy'. have a name - Lazarus ${ }^{35}$ - is described as poor, is dressed in sores and does not feast at all. The rich man has food and friends in abundance, while Lazarus is hungry (longing to be fed with what fell from the rich man's table ${ }^{36}$ and has only $\operatorname{dogs}^{37}$ for companionship. The rich man has the ability to give; Lazarus can only beg, if he is indeed still able to do so. ${ }^{38}$ Moreover, since the gate belongs to the rich man, he is able to pass through it, while Lazarus is not. This difference in situation between the rich man and Lazarus is summarised in Luke 16:25: the rich man receives good things and experiences comfort, while Lazarus receives evil things and experiences anguish.

In Luke 16:22 both the rich man and Lazarus die; and a reversal of their previous respective fortunes takes place. Lazarus is carried away ${ }^{39}$ by the angels to Abraham, where he is comforted (at Abraham's bosom), ${ }^{40}$ while the rich man is buried and finds himself in a place of torment and anguish. Lazarus now has in abundance (water) and is able to give; while the rich man longs for a mere drop of water, ${ }^{41}$ just as Lazarus desired to be fed by the crumbs that fell from the table of the rich man. The situations of the rich man and Lazarus thus have drastically changed: Lazarus is now 'inside', and the rich man is 'outside'. And between them is a chasm that cannot be crossed.

The strategy of the parable, however, is not about opposites. One similarity in the parable can be indicated, a similarity surrounded and highlighted by all the oppositions in the parable: both the rich man and Abraham are unwilling to help the one that needs help. In terms of the strategy of the parable this is its main point. All the oppositions in the parable drive at highlighting this one aspect of its strategy. Many oppositions; only one similarity - the fortunes of the rich man and Lazarus have changed drastically, but one thing has stayed the same: those who have the ability to help, do not help.

This similarity in the strategy of the parable has not received much attention in previous interpretations of the parable. Below it will be argued that this similarity is not only the key to unlocking the meaning of the parable, but may also be key to answering the question as to the parable's authenticity.

\section{Etics}

From an etic perspective, the above emic reading implies several social and cultural conventions (native concepts

35.'Lazarus', which means 'God helps', , is a shortened form of the name Eliezer (or Eleazar), the name of Abraham's servant in Genesis 15.2. That the meaning of this name is indeed important for the interpretation of the parable is indicated below.

36. The food that fell from the rich man's table is not crumbs or food that fell accidentally but pieces of bread that the guests at the rich man's table had used to wipe their hands before throwing them under the table (Herzog 1994:118; Montefiore 1909:538; Oesterley 1936; Snodgrass 2008:425; see Hultgren 2000:112 for an opposite point of view). According to Jeremias (1972:184), rabbinic traditions cite reasons of purity and hygiene for adhering to this practice and command the gleaning of the leftovers for sharing with the poor. This obviously does not take place in the parable, another indication of the conspicuous consumption of the rich man (Herzog 1994:118)

37.According to Scott (1989:151), the dogs that licked Lazarus are most probably wild street dogs, a plague in the ancient world. The dogs are thus not household pets helping him but scavengers (street dogs) seeking nourishment (Leonhardt-Balzer helping hi but 2007:652-653; Snodgrass 2008:425). Derrett (1970:89-91), however, understands after the guests have departed to clean the table droppings (Mk 6:28)

38. Herzog (1994:118-119) opines that Lazarus, because of his situation, was vulnerable to disease, which later makes even begging impossible. His condition is described with the indicative passive of $\beta a \lambda \lambda \omega$ ('thrown down' or 'cast down'), which means that he was probably bedridden or crippled (Fitzmyer 1985:205) and thus not able to beg.

39.See Genesis 5:24 and 2 Kings 2:11.

40. The metaphor 'at Abraham's bosom' suggests a child at a mother's bosom (place of protection), a place of honour at a banquet or the place of the patriarchs ( $\mathrm{Gn}$ 15:15; see also Scott 1989:152; Snodgrass 2008:423). It also suggests a place of hospitability (Scott 1989:153) or honour (Herzog 1994:121), a notion that is taken up further below.

41.According to Jensen (1980:55), this request from the rich man equates him with the dogs that licked Lazarus' sores. 
and perceptions) that construed 'reality' in the first-century Mediterranean world (Elliott 1993:39). Herzog (1994), Hultgren (2000) and Scott (1989), in their analyses of the parable, correctly identified some of the salient cultural scripts of the world that Jesus lived in and that are implied in the parable. The parable assumes the social structure of an advanced agrarian society, in which the rich man and Lazarus exemplify the class disparity of that social structure, the big difference that existed between city and countryside and the oppressive system that it incorporated (Herzog 1994:117-130). It also implies patronage and clientism (one of the most important relationships in aristocratic societies) and the first-century Mediterranean world as a limited-goods society where the social status of the poor and the rich was fixed (Hultgren 2000:115-116; Scott 1989:150-151). To this we can add the lavish meals of the rich man, which functioned as ceremonies to confirm the values and structures of that society, and the pivotal values of honour and shame. Very important also is the figure of Abraham, which evokes the important principle of hospitality. Finally, the physical state of Lazarus relates to the important principle of being socially (and ritually) pure or impure.

Not all the above cultural scripts can be attended to in the analysis that follows. As a discriminating principle that focuses on the strategy of the parable, the unwillingness of both the rich man and Abraham to help those who are in need will be attended to. Attention will therefore be given to patronage and clientism in the first-century Mediterranean world, the social status of being rich or poor and the figure of Abraham, which evokes the principle of hospitality.

\section{The situation of the parable \\ The backdrop of the parable: An advanced agrarian (aristocratic) society}

First-century Palestine was an advanced agrarian (aristocratic) society, divided into the 'haves' (the élite rulers) and the 'have-nots' (the ruled peasantry). The ruling class (the élite) comprised only one to two per cent of the population and lived in the cities while the rest of the population, the peasants (the ruled), lived in the countryside (Fiensy 2007:39; Oakman 2008:58; 2008:51, 133). No middle class existed. Although comprising only one to two per cent of the population, the élite controlled most of the wealth (from one half up to two thirds) by controlling the land, ${ }^{42}$ its produce ${ }^{43}$ and the peasants, whose labour ${ }^{44}$ created the produce (Carter 2006:3; Hanson \& Oakman 1998:69; Horsley 1993:11). Because of the heavy tax burden, most peasants struggled to live above the level of subsistence and accrued heavy debts ('investments' from the élite ${ }^{45}$ ) that they

42.The elite's wealth and power were based in land. They did not rule by way of democratic elections but through hereditary control and the expropriation of land the so-called 'proprietary theory of the state'; Lenski 1966:214-219). They treated controlled (conquered) land as their personal estate to confiscate, distribute, redistribute and disperse as they deemed fit (Fiensy 1991:99-101; Herzog 2005:55; Oakman 2008:124, 147-149).

43. The elite lived at the expense of the non-elite. Local (the Jewish temple aristocracy), regional (Herod and the Herodians) and imperial elites (Caesar) imposed tributes, taxes and rents, extracting wealth from non-elites by taxing (his exposed to thee livels of tibute takn (Oribute consisted of the tributum soll (land tax) and the tributum capitis (poll tax). Next in line, in Galilee, was Herod Antipas, together with the Herodian aristocracy, centred in Sepphoris and Tiberius; Antipas collected tribute especially to support his rule and to finance his extravagant building projects (the building of Tiberius and the rebuilding of Sepphoris). Finally, the temple aristocracy took its share in the form of tithes and offerings to support both the temple and Roman rule. Even the peasantry of Galilee was subjected to this demand, even though the peasants lived outside the jurisdiction of Judaea (Charlesworth 2006; Dunn 2006:208; Fiensy 2007:59; Reed 2000).

44. The elite detested manual labour and thus exploited cheap labour (slaves, day labourers and tenant farmers who had lost their land; Cicero, Duties 1.150: Sirach $38.25-34 ;$ see also Carte 38:25-34; see also Carter 2006:3; Fiensy 2007:34, 72; Hanson $\&$ C
Horsley 1993:11; Oakman 2008:148).

45.Goodman (1987:59-66) describes the Jewish upper class (including the many priestly families) as so excessively wealthy that they could not spend what they had through consumption and the erection of large buildings. This also means that they were always looking for opportunities for investment; of which the extension of could not repay (Goodman 1982:426). The result of this rising indebtedness was the forming of ever larger estates, tenancy and a landless class (Kloppenborg 2006:284-309). The peasantry were constantly threatened with downward mobility and a loss of subsistence, being displaced from smallholder to tenant, then from tenant to dependent day labourer and eventually ending up as part of the expendables of society (such as beggars).

\section{Patronage and clientism}

Patron-client relationships were part and parcel of advanced agrarian societies. ${ }^{46}$ Except for patron-client relationships between élites, the élite also entered into patron-client relationships with the poor and the peasantry. These relationships benefited the élite (the patrons) in terms of the accumulation of honour and status and, from the side of the poor, the day labourers and the peasantry, enabled them to survive (or secure something more than just subsistence living ${ }^{47}$ ). The élite, always seeking to aggrandise their honour and status, competed to add dependent clients (as having only a few clients was considered shameful). 'Clients competed for patrons just as patrons competed for clients in an often desperate struggle to gain economic or political advantage' (Malina \& Rohrbaugh 2003:388). The client's life consisted mostly of salatatio (the morning greeting of the patron to enhance his honour). Menial duties were sometimes expected, although public praise of the patron was considered fundamental. In return, the clients received one meal a day and other petty favours ${ }^{48}$ (Malina \& Rohrbaugh 2003:388). Another aspect of patronage should be noted here, since it has an important bearing on the meaning of the parable. Part of patronage was the hospitium, the relations of host and guest (who were social equals). These relationships, according to Malina \& Rohrbaugh (2003:389), were often formalised in contractual agreements for mutual aid, legal assistance, lodging, medical assistance, burial and protection for as long as a party remained in the city of the host.

\section{Rich and poor}

'[I]n the eastern Mediterranean in New Testament times, "rich" or "wealthy" as a rule meant "avaricious, greedy," while "poor" referred to persons scarcely able to maintain their honor or dignity' (Malina 1987:355). Traditional peasant societies (like those of the first-century Mediterranean) perceived all resources in terms of 'limited goods' and therefore saw wealthy people as 'thieves', who had benefited at the expense of the poor (Malina 1981:71-93; 1987:363). A poor person was therefore someone who could not maintain his inherited status due to circumstances that befell him and his family (like debt, being in a foreign land, sickness or some personal physical accident; those who hunger or thirst, the blind, the ill, the lame, lepers and the deaf [Malina 1981:85]). At the same time, the rich person was one who was able to maintain his status. According to Hollenbach

(footnote 45 continues...)

credit to small farmers became an enormous source. The aim of these investments was to acquire land when the repayment of debts failed. Indebted farmers were frequently enslaved and became the property of their new masters.

46.In aristocratic societies (consisting of 'haves' and 'have-nots'), 'patronage and clientism is a relationship in which, as a special favor, a patron provides for his client access to scarce resources that are not universally accessibe' (Moxnes 1991:243). By entering into a patron-client arrangement, clients rible' (Moxnes p91.243). By encering into a patron-client arrangement, clients relate to their patrons as to superior and more powerful kinsmen, while patrons see to their clients as their dependants (Malina \& Rohrbaugh 2003.38$)$. Patron-client relationships thus describe the vertical dimension of exchange between higher and lower-status people (Neyrey 2004:249)

47. In the economic sphere, this led to an extensive and extractive relationship between patron and client (elite and peasant): leadership was concerned with plundering rather than with developing; taxation existed for the benefit of the elite; resources were exploited for personal benefit; focus was on trade; and the elite was always looking for control over land (mostly by expropriation and the creation of debt; Eisenstadt \& Roniger 1984:208).

48.In terms of the exchange of resources between patrons and clients, Malina (1986:98-106; see also Neyrey 2004:253; 2005:469-470) identifies three types (1986.98-106: see also Noypes of reciprocity. generalised (extrome balanced (the (tidpoint; mutreme solidarity; alruism exm (he 'other'). The last-mentioned kind of reciprocity is clearly applicable in the case of patron-client relationships, where the elite look only to gain from the relationship (e.g. to aggrandise honour or to add dependants in the process of gaining power). 
(1987:57-58), this does not mean that the terms 'poor' and 'rich' in the first-century Mediterranean world did not also have some economic content. In oppressive aristocratic-peasant societies, in which peasants are dominated and exploited by aristocrats, peasants, as such, are the poor and aristocrats, as such, are the rich. The poor and the rich were therefore also permanent groups within society, at least in economic-political terms (Hollenbach 1987:58).

\section{Reading the parable}

The parable of the rich man and Lazarus is a story about the great class disparity in first-century Palestine, about the divide between the urban élite, who controlled all the wealth, power and privilege, and the exploited rural peasantry, who lived in the narrow margin between famine and subsistence (Malina \& Rohrbaugh 2003:295).

In the parable, the élite are represented by the rich man, most probably one of the Jewish aristocracy with official power (he knows Abraham and he wears purple). To show his status, he flaunts his wealth through conspicuous consumption stemming from lavish spending (Fiensy 2007:91). The clothes that he wears (rare and expensive Egyptian linen underwear and purple clothing) are also a status marker: purple is the colour of kings and honourable men, a mark of luxurious living and a sign of official power worn by those who were proud of their wealth. Since he was able to maintain his wealth, he was a man of honour. To enhance his honour and status, he 'made merry' (feasted) every day, most probably with other élites who stood with him in patron-client relationships. Being part of the élite, he also competed for clients among the poor and the peasantry. These patron-client relationships put him in a position to control more and more land, produce and labour.

At the rich man's gate, one of the products of his exploitation, Lazarus, spends his days. Lazarus had become one of the expendables of the society that the rich man and the other élite had created. Lazarus was no longer of any use to the rich man. Since he was placed there every day (Fitzmyer 1985:1131), he could not really beg or take part in the daily salutation of the patron. Nothing could be gained by making Lazarus a client, even in terms of negative reciprocity, and to show him hospitium (looking after his sores, for example) would have made Lazarus his equal. This, of course, would have meant a loss of honour. To him, Lazarus was expendable in every sense of the word.

Lazarus represents the exploited peasantry, the poor and the destitute. The reason why Lazarus ended up at the gate of the rich man can only be speculated upon. He may have been the second or third son of a peasant farmer who had only enough land for the eldest son to inherit, he may have had to leave the family plot and seek work elsewhere because there were too many mouths to feed in a household living below or just at the level of subsistence or his father may have lost his land because of rising indebtedness and eventual foreclosure on his mortgage by one of the exploiting urban élite (Herzog 1994:119). He may even have been a smallholder of inherited land who lost his land because of, inter alia, the excessive tax burden imposed by the ruling élite. Whatever the case may have been, the road that leads to the gate of the rich man is a one-way street: first tenant; then day labourer; eventually, drifting to the city where work is scarce, he did not find work and became a beggar. The parable describes the final stretch of the road that he travels: he becomes malnutritioned and covered with sores, not even able to beg anymore. Lazarus has no honour left ${ }^{49}$ : he is economically poor (Hollenbach 1987:58); poor in the sense that he cannot maintain his status as a peasant smallholder (Malina

49.Maybe the only honour that Lazarus has left is that he does not beg, as can be deducted from Sirach 40:18-30 (in Scott 2001:90): 'Child, do not lead the life of a beggar; it is better to die than to beg. When one looks to the table of another, one's way of life cannot be considered a life. One loses self-respect with another person's way of life cannot be considered a life. One loses self-respect with another person's food, but one who is intelligent and well instructed guards against that.
of the shameless begging is sweet, but it kindles a fire inside him.
1987:355); he has no family ties left; and, above all, he is socially and ritually impure. His name says it all: only God can help.

In the parable, the name 'Lazarus' is not accidental. It typifies the way in which Jesus sided with the poor, the expendables and the socially impure during his day. In a situation where Jesus knew very well that the exploiting rich were only becoming richer and the poor poorer, ${ }^{50}$ Jesus' $^{\prime}$ concern for the poor is not surprising. ${ }^{51} \mathrm{He}$ congratulated the poor and the hungry, ${ }^{52}$ damned the rich and those who were well fed at the cost of the poor $^{53}$ and exhorted the rich to sell their possessions and give to the poor ${ }^{54} \mathrm{He}$ also criticised patronage and clientism based on the principle of negative reciprocity by modelling all personal relations on those of closed kin, that is generalised reciprocity (Oakman 2008:103-107). He encouraged hosts to invite the poor, crippled, lame and blind who could not repay them (exemplified by the parable of the dinner party/wedding feast, which refers to élite hosts, ${ }^{55}$ ) to love their enemies, ${ }^{56}$ to do good and to pray for their abusers, ${ }^{57}$ to lend to others, expecting nothing in return ${ }^{58}$ (a sequence of sayings confirmed by the summary statement in Lk 6:35; see Funk et al. 1993:291), to treat people in the same way as they would want to be treated ${ }^{59}$ and to forgive the debt of others ${ }^{60}$ (paralleled in the parable of the unforgiving slave). Jesus even tried to turn the hearts of the powerful to the powerless and dishonoured poor ${ }^{61}$ (Oakman 2008:161) and criticised those patrons who were constantly looking for new ways to enhance their honour by means of salutations by their clients. ${ }^{62}$ Moreover, he ate indiscriminately with the so-called 'sinners' ${ }^{\prime 63}$ and healed the sick. ${ }^{64}$ From this, it becomes clear that Jesus' sympathies indeed lie with the poor..$^{65}$ There is help, after all, for Lazarus - especially in a kingdom where God is the patron and not the ruling aristocratic élite. ${ }^{66}$ Where God is

50.Mark 4:25//Q 19:26 (Lk 19:26/Mt 13:12)//GThom 41:1-2.

51.Jesus' concern for the poor can be inferred from several sayings in the New Testament that most probably - in terms of the criteria of independent, early Testament that most probably - in terms of the criteria of independent, early to the historical Jesus. For a definition and discussion of the criteria, see Funk to the historical Jesus. For a definition and discussion of the criteria, see Funk (1993:19-33),

52.Respectively Q 6:20 (Lk 6:20/Mt 5:3)//GThom 54 and Q 6:21 (Lk 6:21/Mt 5:6)// GThom 69:2.

53.Although this saying is attested only in Luke 6:24-25, it most probably, in terms of the criterion of coherence, goes back to Jesus.

54.According to Fiensy (2007:115-118), all the call stories in the gospels (e.g. Mk 1:16$18,19-20 ; 2: 14 ; 10: 17-22$ and their synoptic parallels) indicate that discipleship 18, the 20; 14 ; $10: 1722$ and and the renunciaton

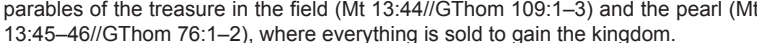
5.Respectively Luke 14:12-14 and Q 14:16-24 (Lk 14:16-24/Mt 22:2-14)//GThom 64:1-12.

56.Q 6:27 (Lk 6:27b/Mt 5:44).

57.Q 6:28 (Lk 6:27c-e/Mt 5:44b)

58.Q 6:30 (Lk 6:30/Mt 5:42)//GThom 95:1-2//Did 1:4b, 5a

59.Q 6:31 (Lk 6:21/Mt 7:12a)//GThom 6:3.

60.Respectively Q 6:37 (Lk 6:37c/Mt 6:14-15)//Mark 11:25 and Matthew 18:23-35.

61.According to Oakman (2008:161), this can be inferred from Luke in his discriminating use of the radical Jesus tradition (Lk 12:48; 19:8-9; 22:26). The fact that Luke 22:26 finds support in Mark 10:31//Q13:30 (Lk 13:30/Mt 19:30 and 20:16)//GThom $4: 2-3$ makes this a plausible argument.

62.Mark 12:38-40/Matthew 23:5-7/Luke 20:45-46//Q 11:43 (Lk 11:43/Mt 23:6b-7a).

63.P Oxy 1224 2:5//Mark 2:13-17a/Matthew 1:9-12/Luke 5:27-31//Gos Eb 1c/Luke 15:1-2 (Crossan 1991:440).

64.Almost all historical Jesus scholars agree that Jesus practised an open table and healed the sick (including conducting exorcisms).

65.Jesus' concern for the poor thus stands clearly in line with the priestly, Deuteronomic wisdom and prophetic traditions in the Old Testament to protect the poor from the exploitative practices and systemic violence of the rich (e.g. Ex 22:25; Lv 19:10; Dt 15:4-11; Pr 14:31; 22:9, 22; Is 3:14-15; Am 2:6-7; see Fiensy 2007:96, 132).

66.Many Graeco-Roman philosophers also criticised many patron-client relationships of their day. They saw virtue (moral goodness and propriety) as more importan than benefaction, the ideal being generalised reciprocity (e.g. Seneca, Benefits 
patron, the gate is passed through. This, however, is neither the kind of patron that the rich man is nor the way in which he acts. Nothing prevents him from doing otherwise. The gate is there, it even belongs to him. But he does not pass through it - simply because there is nothing in it for him to do so. He could only lose some honour.

When the rich man dies, he has the opportunity of viewing the way that things are from the other side of the gate. He is confronted with the kind of patronage towards and of solidarity with the poor and the destitute that Jesus advocates. Abraham, the example par excellence of hospitality in the Old Testament, ${ }^{67}$ clearly embodies Jesus' attitude towards the poor. ${ }^{68}$ Lazarus is sitting at the table (bosom) of Abraham, where hospitium has been extended to him. But the rich man, although being in torment and thirsty, is not worried: Abraham is his father too and, in line with what is known of Abraham's hospitality, it will be extended to him as well. Now, he is the one who is in need and, just as in the case of Lazarus, those who are in need are looked upon favourably by Abraham. He just has to ask.

But then the surprise in Jesus' parable. Abraham is not willing to help. Abraham does not even offer one drop of water to be licked from Lazarus' finger. Even the dogs that licked Lazarus' sores were better off. This is indeed an oxymoron - Abraham not being hospitable? How is this possible? This simply cannot happen where Abraham is involved. But it does happen. The unthinkable happens: Abraham does not show hospitality. And then the big and final shock: this gate cannot be opened. It cannot be passed through. It has been closed forever.

This is the gist of the parable. When patrons who have in abundance do not pass through the gate to the poor, a society is created wherein a chasm so great is brought into existence between rich (the élite) and poor (the peasantry) that it cannot be crossed. The worlds of the urban élite and the peasantry drift so far apart that the gap between them eventually cannot be closed. Pass through the gate while you can. Just as unthinkable as it is for Abraham not to do what he can, so is it unthinkable for those who can help. Abraham, being the example of hospitality, has no reason to turn his back on the rich man. The same holds for the rich man: nothing stood in the way of his helping Lazarus. It was not impossible to help Lazarus. The protection

4.2.4: 'The bestowal of . . a benefit ... is a mark of virtue, and to bestow it for any other reason other than merely the bestowing of it is a most shameful act'; and Benefits 4.11.3. 'Give to the one who, though poor, is good; for he will be gratefull in the midst of extrem have. It is not gain that I try to get from a benefit; nor plil have. li is not gain that try to get content with giving pleasure to one human being, I shall give with the single purpose of doing what lought). Benefits were seen as goodwill - more important than the benefit itself was the spirit in which a gift was given: Seneca also makes interesting remarks on the way in which benefits should be given: one should always give benefits 'willingly, promptly and without hesitation' (Seneca, Benefits 2.1.1) and one should always try to anticipate one's own desire and indulge in giving that to someone else, even before someone has to beg (Seneca, Benefits 2.2.1). 'Therefore we ought to divine each man's desire, and, when we have discovered it, he ought to be freed from the grievous necessity of making a request; the benefit that takes the initiative, you may be sure, will be the one that is agreeable and destined to live in the heart' (Seneca, Benefits 2.1.2). Also: 'Just as in the case of the sick suitability of food aids recovery, and plain water given at the right time serves as a remedy, so a benefit, no matter how trivial and commonplace it may be, if it has been given promptly, if not an hour has been wasted, gains much in be, if it has been given proins much in value and wins meen laggard

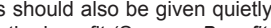
so that they will be known only to those who receive the benefit (Seneca, Benefits 2.9.2). Pleasure should not come from being seen to do a favour but from doing a favour itself (Seneca, Benefits 2.10.3). And: 'The gifts that please are those that are bestowed by one who wears the countenance of a human being, all gentle and kindly; by one who, though he was my superior when he gave them, did not exalt himself above me, but, with all the generosity in his power, descended to my own level, and banished all display from his giving; who thus watched for the suitable moment for the purpose of coming to my rescue with timely, rather than with necessary, aid' (Seneca, Benefits 2.13.3). And, finally: 'The more need a man has of a benefit, the greater is the benefit he receives' (Seneca, Benefits 3.35.3) When these opinions of Seneca (a coeval of Jesus) are related to the relationship between the rich man and Lazarus, they are indeed interesting. See also Virgil (Aeneid 6.600) for the punishments for 'bad' patrons.

67.For a description of Abraham's hospitality, see Scott $(1989: 87,153)$ and Herzog (1994:130)

68. Contra Leonhardt-Balzer (2007:654), who views Abraham not as a character in the parable but as the voice of God. of his status and honour, however, made it impossible. And, when this happens, nobody can become part of the kingdom neither Lazarus, nor the rich man. This is the result of patrons not being patrons. Real patrons are children of Abraham and they look after the poor (Lk 19:8-9).

\section{A parable of Jesus?}

The question of the authenticity of the parable can now be answered. From the above, it is clear that Abraham's hospitality embodies Jesus' attitude towards the poor. The parable also embodies the nucleus of Jesus' teaching on topics like patronage, power and privilege, class, status, generalised reciprocity and the economic exploitation of the peasantry by the ruling élite. The ideas contained in the parable surely are his and are paralleled in some of his parables that can be traced back to the layer of the historical Jesus (such as in Lk 10:30-35, 11:5-8, 14:16-24). The way in which the kingdom is described in the parable (including those with so-called 'impurities') is paralleled in the parables of the mustard seed (Q 13:18-19 [Lk 13:18-19/Mt 13:3132)//GThom 20:1-4) and the leaven (Q 13:20-21 [Lk 13:20-31/Mt 13:33]//GThom 96:1-2; see Scott 2001:119-124). The parable, most interestingly, is also paralleled in the Gospel of the Nazoreans in its commentary on Matthew 19:16-30 $0^{69}$. In its commentary on Matthew 19:16-30, it has, as content, a parallel of the situation pictured in Luke 16:19-26: the poor, called 'sons of Abraham', are being mistreated by the rich ('thy house is full of many good things and nothing at all comes forth from it to them [the poorEvE])'. Finally, the parable also highlights what can be called the main focus of the historical Jesus' main activity, aptly described by Oakman (2008:296): 'Jesus' historical activity was essentially about politics and the restructuring of society, and not about religion or theology.'

\section{REFERENCES}

Aalen, S., 1967, 'St. Luke's gospel and 1 Enoch', New Testament Studies 13, 1-13.

Bauckham, R., 1998, The fate of the dead: Studies on the Jewish and Christian apocalypses, Brill, Leiden.

Beare, F.W., 1962, The earliest records of Jesus, Abingdon Press, New York.

Bultmann, R., 1963, History of the synoptic tradition, Blackwell, Oxford.

Cadoux, A.T., 1930, The parables of Jesus: Their art and use, James Clarke, London.

Cameron, R., 1982, The other gospels: Non-canonical gospels texts, Westminster Press, Philadelphia.

Carter, W., 2006, The Roman Empire and the New Testament: An essential guide, Abingdon Press, Nashville.

Cave, C.N., 1969, 'Lazarus and the Lukan Deuteronomy', New Testament Studies 15, 319-325.

Charlesworth, J.H. (ed.), 2006, Jesus research and archeology: A new perspective, William B. Eerdmans Publishing Company, Grand Rapids.

Charlesworth, J.H., 2006, 'Jesus research and archeology: A new perspective', in J.H. Charlesworth (ed.), Jesus research and archeology: A new perspective, pp. 11-63, William B. Eerdmans Publishing Company, Grand Rapids.

Crossan, J.D., 1973, In parables: The challenge of the historical Jesus, Harper \& Row, New York.

Crossan, J.D., 1991, The historical Jesus: The life of a Mediterranean Jewish peasant, HarperSanFrancisco, San Francisco.

Derrett, J.D.M., 1970, Law in the New Testament, Darton, Longman \& Todd, London.

Donahue, J.R.,1988, The gospel in parable: Metaphor, narrative and theology in the Synoptic gospels, Fortress Press, Philadelphia.

Dunn, J.D.G., 2006, 'Did Jesus attend the synagogue?' in J.H. Charlesworth (ed.), Jesus research and archeology: A new perspective, pp. 206-222, William B. Eerdmans Publishing Company, Grand Rapids.

69. This gospel has as content 'material ... which ... in some instances reflects early traditions of Jesus' (Cameron 1982:98). 
Eisenstadt, S.N. \& Roniger, L., 1984, Patrons, clients and friends: Interpersonal relations and the structure of trust in society, Cambridge University Press, Cambridge.

Elliott, J.H., 1993, What is social-scientific criticism? Fortress Press, Philadelphia.

Fiensy, D., 1991, The social history of Palestine in the Herodian period: The land is mine, Edwin Mellen Press, New York.

Fiensy, D., 2007, Jesus the Galilean: Soundings in a first century life, Gorgias Press, Piscataway.

Fitzmyer, J.A., 1985, The gospel according to Luke X-XXIV. Vol II Doubleday, New York.

Funk, R.W., Hoover, R.W. \& The Jesus Seminar, 1993, The five gospels: The search for the authentic words of Jesus, Macmillan, New York.

Funk, R.W., Scott, B.B. \& Butts, J.R., 1988, The parables of Jesus: Red letter edition. The Jesus Seminar, Polebridge Press, Sonoma.

Goodman, M., 1982, 'The first Jewish revolt: Social conflict and the problem of debt', Journal of Jewish Studies 33, 402-429.

Goodman, M., 1987, The ruling class of Judaea, Cambridge University Press, Cambridge.

Gressmann, H., 1918, Von reichen Mann und armen Lazarus, Verlag der Königliche Akademie der Wissenschaften, Berlin.

Hadas, M., 1977, 'Rabbinic parallels to Scriptores Historae Augustae', in H. Fischel, (ed.), Essays in Greco-Roman and related Talmudic literature, pp. 43-47, Htav, New York.

Hanson, K.C. \& Oakman, D.E., 1998, Palestine in the time of Jesus: Social structures and social conflicts, Fortress Press, Minneapolis.

Hendrickx, H., 1986, The parables of Jesus, Harper \& Row, San Francisco.

Herzog, W.R., 1994, Parables as subversive speech: Jesus as pedagogue of the oppressed, Westminster, Louisville.

Herzog, W.R., 2005, Prophet and teacher: An introduction to the historical Jesus, Westminster John Knox Press, Louisville.

Hock, R.F., 1987, 'Lazarus and Micyllus: Greco-Roman backgrounds to Luke 16:19-31' Journal of Biblical Literature 106(3), 447-463.

Hollenbach, P., 1987, 'Defining rich and poor using the social sciences', in K. Richards (ed.), Society of Biblical Literature 1987 Seminar Papers, pp. 50-63, Society of Biblical Literature, Atlanta.

Horn, F.W., 1983, Glaube und Handeln in der Theologie des Lukas, Vandenhoeck \& Ruprecht, Göttingen.

Horsley, R.A., 1993, Jesus and the spiral of violence: Popular Jewish resistance in Roman Palestine, Harper \& Row, San Francisco.

Hughes, F.W., 1993, 'The parable of the rich man and Lazarus [Luke 16:19-31] and Graeco-Roman rhetoric', in S.E. Porter \& T.H. Olbricht (eds.), Rhetoric and the New Testament: Essays from the 1992 Heidelberg Conference, pp. 29-41, Sheffield Academic Press, Sheffield.

Hultgren, A.J., 2000, The parables of Jesus: A commentary, William B. Eerdmans Publishing Company, Grand Rapids.

Hunter, A.M., 1960, Interpreting the parables, Westminster Press, Philadelphia.

Jensen, H.J.L., 1980, 'Diesseits und Jenseits des Raumes eines Textes. Textsemiotische Bermerkungen zur Erzählung: Von reichen Mann und armen Lazarus', Linguistics and Biblical Criticism 47, 39-60.

Jeremias, J., 1972, The parables of Jesus, Charles Scribner's Sons, New York.

Jones, P.R., 1999, Studying the parables of Jesus, Smyth \& Helwys, Macon.

Jülicher, A., 1910, Die Gleichnisreden Jesu, Mohr, Tübingen.

Kissinger, W.S.,1979, The parables of Jesus: A history of interpretation and bibliography, The Scarecrow Press, Metuchen.

Kloppenborg, J.S., 2006, The tenants in the vineyard: Ideology, economics, and agrarian conflict in Jewish Palestine, Mohr Siebeck, Tübingen

Lenski, G.E., 1966, Power and privilege: A theory of social stratification, McGraw-Hill, New York.

Leonhardt-Balzer, J., 2007, 'Wie kommt ein Reicher in der Abrahams Schoß? (Vom reichen Mann und armen Lazarus)', in R. Zimmermann (Hrsg.), Kompendium der Gleichnisse Jesu, pp. 647-660, Gütersloher Verlagshaus, Munich.
Louw, J.P. \& Nida, E.A., 1988, Greek-English lexicon of the New Testament based on semantic domains. Volume 1: Domains, National Book Printers, Goodwood.

Malina, B.J., 1981, The New Testament world: Insights from cultural anthropology, John Knox Press, Atlanta.

Malina, B.J., 1986, Christian origins and cultural anthropology: Practical models for biblical interpretation, John Knox, Atlanta.

Malina, B.J., 1987, 'Wealth and poverty in the New Testament and its world', Interpretation 41, 354-367.

Malina, B.J. \& Rohrbaugh, R.L., 2003, Social science commentary on the Synoptic Gospels, Fortress Press, Minneapolis.

Manson, T.W., 1949, The sayings of Jesus, SCM, London.

Marshall, I.H., 1963, Eschatology and the parables, Tyndale Press, London.

Marshall, I.H., 1978, The gospel of Luke, Eerdmans, Grand Rapids.

Mealand, D.L., 1980, Poverty and expectation in the gospels, SPCK, London.

Montefiore, H.W., 1909, The Synoptic Gospels, vol. II, Macmillan, London.

Moxnes, H., 1991, 'Patron-client relations and the new community in Luke-Acts', in J.H. Neyrey (ed.), The social world of Luke-Acts: Models for interpretation, pp. 241-268 Hendrickson, Peabody.

Neyrey, J.H., 2004, Render to God: New Testament understandings of the divine, Fortress Press, Minneapolis.

Neyrey, J.H., 2005, 'God, benefactor and patron: The major cultural model for interpreting the deity in Greco-Roman antiquity', Journal for the Study of the New Testament 27(4), 465-492.

Nickelsburg, G.W.E., 1979, 'Riches, the rich, and God's judgment in 1 Enoch 95-105 and the gospel according to Luke' New Testament Studies 25, 324-344.

Oakman, D.E., 1986, Jesus and the economic questions of his day, Edwin Mellen Press, New York.

Oakman, D.E., 2008, Jesus and the peasants, Cascade Books, Eugene.

Oesterley, W.O.E., 1936, The gospel parables in the light of their Jewish background, SPCK, London.

Pax, E., 1975, 'Der Reiche und arme Lazarus: Eine Milieustudie', SBFLA 25, 254-268

Perkins, P., 1981, Hearing the parables of Jesus, Paulist Press, New York.

Rauschenbush, W., 1950, A gospel for the social awakening: Selections from the writings of Walter Rauschenbush, Association Press, New York.

Reed, J.L., 2000, Archaeology and the Galilean Jesus: A re-examination of the evidence, Trinity Press, Harrisburg.

Regalado, F., 2002, 'The Jewish background of the rich man and Lazarus', Asia Journal of Theology 16(2), 341-348.

Schinder, F. \& Stenger, W., 1979, 'Die offene Tür und die unüberschreitbare Kluft', New Testament Studies 25, 273-283.

Schottroff, L., 2006, The parables of Jesus, transl. L.M. Maloney, Fortress Press, Minneapolis.

Schottroff, L. \& Stegemann, W., 1978, Jesus von Nazareth: Hoffnung der Armen, Kohlhammer, Stuttgart.

Schweizer, E., 1984, The good news according to Luke, transl. D. Green, John Knox, Atlanta.

Scott, B.B., 1989, Hear then the parable: A commentary on the parables of Jesus, Fortress Press, Minneapolis.

Scott, B.B., 2001, Re-imagine the world: An introduction to the parables of Jesus, Polebridge Press, Santa Rosa.

Segundo, J.L., 1985, The historical Jesus of the Synoptics, transl. J. Drury, Orbis Books, Maryknoll.

Smith, B.T.D., 1937, The parables of the synoptic Gospels: A critical study, Cambridge University Press, Cambridge.

Snodgrass, K.R., 2008, Stories with intent: A comprehensive guide to the parables of Jesus, William B. Eerdmans Publishing House, Grand Rapids.

Stein, R.H., 1981, An introduction to the parables of Jesus, The Westminster Press, Philadelphia.

Talbert, C., 1982, Reading Luke, Crossroad, New York.

Tatum, W.B., 1999, In quest of Jesus, Abingdon, Nashville. 
Theissen, G. \& Mertz, A., 1998, The historical Jesus: A comprehensive guide, Fortress Press, Minneapolis.

Torrance, D.W. \& Torrance, T.F., 1972, Calvin's commentaries: A harmony of the gospels Matthew, and Luke, transl. A.W. Morrison, Saint Andrews Press, Edinburgh.

Via, D.O., 1972, The parables: Their literary and existential dimension, Fortress Press, Philadelphia.

Wailes, S.L., 1987, Medieval allegories of Jesus' parables, University of California Press, Berkeley.
Wallace, M.I., 2006, 'The rule of love and the testimony of the Spirit in contemporary Biblical hermeneutics', in A.G. Padgett \& R.K. Keifert (eds.), But is it all true? The Bible and the question of truth, pp. 66-85, Eerdmans, Grand Rapids.

Wright, N.T., 1996, Jesus and the victory of God, Fortress Press, Minneapolis. 